DE DE GRUYTER

OPEN

DOI: $10.1515 /$ aa-2015-0011

\title{
The fight between right and wrong: Exploring morality in M. L. Stedman's novel The Light between Oceans
}

\section{Natália Čechová}

Natália Čechová is a $\mathrm{PhD}$ student at the Department of English and American Studies, Constantine the Philosopher University in Nitra. She is currently working on her dissertation entitled Aesthetic Distance in Contemporary Fiction, in which she focuses on the study of various techniques that contemporary authors use to break the aesthetic illusion readers want to experience while reading a book.

\begin{abstract}
The paper explores the eternal theme of morality and its effects on human thoughts and actions as depicted in M. L. Stedman's debut novel The Light between Oceans (2012). The aim is to study how her characters, facing a demanding post-war environment, deal with morally challenging events in their lives and how they are able to fight the socially accepted concepts of what is right and what is wrong as well as the consequences of the serious decisions they make. Tom Sherbourne, a WWI veteran, settles down to his new job as lighthouse keeper and marriage with Isabel, but instead of finding peace, he faces several moral dilemmas which create a cold distance between him and his wife, as well as between his pre-war and actual self. In this sense, the paper tries to describe what Stedman has to say - through Tom's character - about the nature of human morality and decision-making and how tragic their consequences might be.
\end{abstract}

Motto: "You only have to forgive once. To resent, you have to do it all day, every day. ... We always have a choice. All of us."

(The Light between Oceans)

In 2012, Australian author M. L. Stedman published her debut novel The Light between Oceans to great critical acclaim. It is a complex and beautifully written work dealing with some of the most thought-provoking and philosophical concepts such as the internal struggle between right and wrong, the consequences of making decisions, the fight between morality and basic human instincts, the acceptance of fate and the healing power of forgiveness.

The novel follows the life of Tom Sherbourne, who returns to his home country of Australia after four agonizing years spent on the Western Front during the First World War. He is a shattered man, a veteran who struggles to overcome the torturous reminiscences of the 
war and return back to normal life. He takes a job as a lighthouse keeper on Janus Rock, a solitary island located half a day's journey from the coast of Western Australia, where a supply boat comes every three months and shore leave is possible every three years. He brings there his young and beautiful wife Isabel and it seems that their life could not be any better. However, their happiness is overshadowed by numerous tragedies as Isabel overcomes two miscarriages and one stillbirth. Two weeks after the third grave appears on the island, Isabel hears a baby crying. She wonders if she has gone insane, but soon a boat is washed ashore with a dead man and a living new-born on board. Tom is a man who stands firmly by his moral principles and he wants to report the finding immediately, but Isabel persuades him to keep the baby and raise it as their own. The decision made that day influences their lives forever. Isolated on the island, they forget that there may be a mother desperately searching for her child. Only when they come back to civilization do they learn how devastating the outcome of their decision has been.

Tom Sherbourne is a man of strict moral principles. Throughout his life, he tries to act only after thinking properly about the potential consequences of his decisions. He knows that the border between right and wrong is very fine and fragile, but he believes that his actions are based on good decisions. However, he soon learns that what he might understand as right for himself is not necessarily right for others. In fact, his moral values were seriously shaken during his service in the First World War. There he understood that simple "live and let live" does not apply any more. You have to kill, otherwise you will be killed. Four years later, his soul is still immersed in darkness; his brain cannot process the fact that he was lucky to survive while his comrades were dying in front of his eyes and he could not do anything to help them or make their pain disappear:

On the Lights, Tom Sherbourne has plenty of time to think about the war. About the faces, the voices of the blokes who had stood beside him, who saved his life one way or another; the ones whose dying words he heard, and those whose muttered jumbles he couldn't make out, but who he nodded to anyway. Tom isn't one of the men whose legs trailed by a hank of sinews, or whose guts cascaded from their casing like slithering eels. Nor were his lungs turned to glue or his brains to stodge by the gas. But he's scarred all the same, having to live in the same skin as the man who did the things that needed to be done back then. He carries that other shadow, which is cast inward (Stedman, 2013, pp. 22-23).

We may ask what morality is then. Tom was supposed to forget about what was right and do what his inner self had rejected. His moral values were turned upside down. Now he 
has to return back to his original self. He has to find his inner strength, but after years spent in the company of ever-present horror and death, this goal seems to be unreachable.

$\mathrm{He}$ is in need of a quiet place far away from anything that could remind him of the atrocities of war. He needs to calm down in order to find what truly matters in life. That is the reason he chooses to spend some time on the solitary island of Janus Rock, miles away from civilization. It transfers him to a place that helps him explore his inner self. There he is able to find a state of mind that makes him feel free and independent like a bird that has no limits: "Very slowly, he turned a full circle, taking in the nothingness of it all. It seemed his lungs could never be large enough to breathe in this much air, his eyes could never see this much space, nor could he hear the full extent of the rolling, roaring ocean. For the briefest moment, he had no edges" (Stedman, 2013, p. 53).

Even though the place is viewed as harsh and inhospitable, nothing could be worse than the fields where the war took place. In general, life in lighthouses was not easy. The lighthouse keepers and their families lived there in isolation, only rarely visited by people who brought supplies and other things important for the management of the light. There is a poem hand-written in a manual for lighthouse keepers depicting the reputation that such a life had: "The man stood at the pearly gates looking all tired and old. He meekly asked the man of fate for admission to the fold. 'What have you done,' Saint Peter asked, 'to gain admission here?' 'I was in the Lighthouse Service and got leave once a year.' The gate swung open widely as Saint Peter tolled the bell. 'Come in,' he said, 'and take a harp. You've had enough of hell" (qtd. in Kijas, p. 20). For Tom, however, the isolation is not a problem at all. In fact, it is the thing he seeks most in order to recover from his past.

What Tom is enduring is a serious psychological trauma known as shell shock, which is a mental disorder that afflicted many of the soldiers who survived the Great War. He cannot sleep properly due to nightmares full of blood, pain and death; he cannot stop thinking about what he experienced in the war and - what is even more painful - he is not able to speak about it as no civilian could understand what the soldiers went through in the trenches. Bodily wounds were nothing in comparison with psychological wounds:

A person could only take so much. He'd seen it often enough. Lads who'd turned up full of ginger and ready to give Fritz hell, who'd survived the shelling and the snow and the lice and the mud, for years sometimes. Then something in them just packed up and went home - went somewhere deep inside where they couldn't be touched. Or sometimes they turned on you, came at you with a bayonet, laughing like a maniac and crying at the same 
time. Christ, when he thought back to his own state by the time it was all over... (Stedman, 2013, p. 324).

Tom has become a mentally unstable man, a man who is not able to see the world like other people do, simply because they were not in the war. They did not see the brutality the soldiers experienced; they did not bury their mates or what was left of their mates. Even though the war affected the entire world, as mothers lost their sons, sisters lost their brothers and wives lost their husbands, they were not there when life turned into death in less than a second. The fictional Tom experiences very similar consequences of the war to the real Ted Smout, one of Australia's World War I veterans who confessed to the press how difficult it was to speak about the memories of the bloody years: "I still dream occasionally. Wake up at night and realise, “Oh, I'm in bed." [...] I think there's a subconscious way of putting it in the background. And you never talk about it cause there's nobody to talk to about it. All the diggers are dead and anyone else wouldn't understand. I mean there's no way you could convey to the ordinary civilians the horrors that happened in the war. No way. Indescribable" (“Ted Smout", p. 5).

A hundred years have passed since the outbreak of the First World War and nowadays there are only journal entries left where we can learn what the soldiers experienced and how they felt. For us, it is impossible to imagine what the life of a soldier was like. We can see photographs and videos depicting the war, and - hopefully - we will not experience the battles the way that the soldiers did. For that reason we can hardly understand why they suffered from shell shock and why it was a disease only the fittest could recover from. One soldier left the following lines written in his journal:

I was one of the first to be hit, and, despite the pain of the wounds and the terror that I should bleed to death before I was attended to, I kept on repeating to myself 'It's over now. It's over now.' And so it was, for me at any rate. When I came out of the hospital many months later the Armistice had been signed. I was just twenty-one years of age, but I was an old man cynical, irreligious, bitter, and disillusioned. I have been trying to grow young ever since (qtd. in Livengood, p. 2).

One of the recommended treatments for shell shock was to repress the thoughts and memories of the war and concentrate on different ones. Simply said, the veterans should think about something positive and pleasant. However, it was easy to say but much more difficult to do, as the minds of the survivors were constantly straying back to the horrific experiences of 
the war. Tom suffered in a very similar way. Even though he was doing his best to forget his past, the war kept returning back to him in his sleep.

Tom never succeeded in becoming the man from the years before the war, but he was still trying to be the best version of himself. His love for Isabel helped him a lot. She made him smile; her easy-going attitude made him relaxed and her lively demeanour helped him to think positively as well. Moreover, the job as a lighthouse keeper gave him another meaning to life. The keepers' duty was stated very simply, but still, their job influenced the lives of other people: "Your duty is to ensure that the aid to navigation under your control is operating efficiently at all times. The safety of life at sea depends on you" (qtd. in Kijas, p. 13). Looking at it from Tom's perspective, one assumes that although he was taking lives during the war, now he had a priceless chance to save them, as, for instance, when a crying baby girl was washed ashore on his little island. It was simple to save her, but Tom's morality started to be challenged again. He found himself trapped within a torturous inner dilemma, because while it would be easy to claim the baby as their own and never reveal the secret to the outside world, there still was a chance that the baby's mother was alive and looking for her child and thus it was necessary to report the event. Which way should he choose? What decision should he make? And what would happen in the aftermath of it? These were the questions his mind was facing in a painful battle with morality. Only Isabel's sorrow and pain over losing her third child led him to make a decision which he viewed as right at the moment, although it proved to be nothing but fatal in the end. Isabel was his other half; she completed him. This was probably the reason why he decided to satisfy her maternal need and see her happy again.

In the novel, Isabel represents unbound maternal instinct, which is presumably one of the strongest instincts that human beings have. It is even stronger than a man's sense of right and wrong; it makes him kneel down and surrender to its power. Moreover, Isabel is also a woman who feels the tragic consequences of the war. She is aware of the fact that humankind has been shattered and that millions of people are alive no more. She accepts the burden in order to do her small part in saving the population, but due to her numerous miscarriages, she starts to feel that she is not the one to be the saviour. It must depress her profoundly and shake the way she views herself in the eyes of her husband and society, even though she is wrong in this assumption. Such a state changes her a lot. She was a happy and smiling girl when Tom met her for the first time. She also suffered from the atrocities of war as her two brothers died there, but she managed to retain her bright vision of the future. She did not allow the sadness to take over her natural right to live. In her dreams, she pictured herself as a happy wife with a huge family and she did her best to make that dream come true. This vision helped Tom 
realize that there is still life in the future and that Isabel is the woman who could make him live life to the fullest again. Thanks to her, it was easier to forget about his past and concentrate more on what was about to come. Now Isabel is a heartbroken young wife who cannot get over the tragedies that made her marriage less happy than it would otherwise be. She feels like a failure as the dream she had earlier somehow has lost its brightness.

However, the baby that she and Tom save on the island brings back her sense of life. She considers it a gift from God. It is a tiny bundle of happiness that she believes God sent them to raise as their own. Her maternal instinct comes to life again and Tom sees that the baby has changed her. Her eyes are shining again. Despite his strong inclination towards rules and principles, he is not able to take the child out of her arms and send it back to civilization. Such a situation plunges him into a tough moral conflict. On the one hand, there is the moral truth claiming that the child must have its family somewhere and that he has to report it, but on the other hand there is a woman embracing the child as her own and Tom is the one who can make her maternal instinct blossom. That being considered, Isabel's happiness depends on him.

The fight between right and wrong that Tom goes through seems to be unresolvable, but somehow his past assumes the role of main arbiter. It was Tom who once said that war changes the way people think and act: "Being over there changes a man. Right and wrong don't look so different any more to some" (Stedman, 2013, p. 29). In other words, a man is not able to differentiate between what is right and what is not right and thus he is unable to see the effects of his decisions clearly. Tom suffers from the same "illness". He makes the ultimate decision based on what he feels is good at the time, rather than what is good in the long run.

The setting of the novel - a solitary island far away from civilization - facilitates the process of decision-making. The isolation of the lighthouse somehow fools the couple and helps them believe that what they are doing is right. They do not see the effects of their decision, because there is no one to see affected by it. There is no moral mirror which would reflect the horrific consequences of their act. Even though Tom is aware of the fact that the child has a real mother somewhere and is driven by the need to do the right thing at last, which is to return the child, the absence of people on Janus Rock helps him believe the lie more easily: "When he wakes sometimes from the dark dreams of broken cradles, and compasses without bearings, he pushes the unease down, lets the daylight contradict it. And isolation lulls him with the music of the lie" (Stedman, 2013, p. 218). 
Tom and Isabel's position in the lie and towards the lie resembles the geographical appearance of Janus Rock. While one part of the island is beautiful and welcoming, with the shores smoothly merging into a rather peaceful ocean, the other part is its complete opposite: "The other side of the island looked back, fretful, towards the Australian mainland nearly a hundred miles away, not quite belonging to the land, yet not quite free of it, the highest of a string of under-sea mountains that rose from the ocean floor like teeth along a jagged jaw bone, waiting to devour any innocent ships in their final dash for harbour" (Stedman, 2013, p. 14). Now with her beloved Lucy in her arms, Isabel looks vividly into the future. She has found happiness and looks forward to what the future will bring. She believes that her husband's heart has been melted by their daughter and that something in him has finally been moved. She observes them playing together and she sees that Tom loves his new role in life. However, she cannot enter into his mind and find out that Tom is fighting a dreadful battle therein. He is permanently reminded of the fatal decision he has made and his attacks of conscience are often too agonizing for him to bear. Unwillingly, he creates a wall between him and Isabel, because every time he sees her happy, he feels horrible: "[A] sliver of uncrossable distance has slipped between them: an invisible, wisp-thin no man's land" (Stedman, 2013, p. 218). Tom wants badly to get rid of the lie and do the right thing, but he cannot tear himself away from the lie since he shares an equal part of it with his wife. Metaphorically, he is the Janus Rock - or at least its less hospitable part - that wants to tear away from the lie but cannot, because it is fatefully connected to it for good. Moreover, nothing has made him so uncertain than loving a child that he knows belongs to someone else. It makes the situation he appears in even more unbearable. He must feel like a hypocrite because what he does is not in harmony with what he feels in the most secretive depths of his heart: "He struggles to make sense of his emotions - how he can feel both tenderness and unease when she kisses him goodnight, or presents a grazed knee for him to kiss better with the magic power that only a parent has. For Isabel, too, he is torn between the desire he feels for her, the love, and the sense that he cannot breathe. The two sensations grate at one another, unresolved" (Stedman, 2013, p. 225).

The lighthouse is also a symbol of Tom and particularly of his feelings towards Lucy. Its light constantly turns for a specific time period. Looking at a lighthouse at night, we can see only the light which appears and disappears in a span of seconds. The light is replaced by darkness and vice versa. The same process takes place inside Tom. When Lucy is around, Tom feels that his heart is covered in light. He stops thinking about the way in which she came into his family or about the fate that eventually has to be fulfilled. Moreover, the name 
"Lucy" means light and thus she is the light of Tom and Isabel's lives. She is the light between two oceans. However, when Lucy is not around, Tom's world is covered in darkness again. The lie and its consequences are the only two things that he can think about at this time. It goes together with the lighthouse and the meaning it has for people who depend on it. At night, we see only the light it produces. We cannot see the building or the land it is built on. The light is there for sailors; it has to shine for them, not for the lighthouse keeper. The light cannot illuminate the space closest to the lighthouse and, metaphorically, it cannot illuminate the inside of Tom. That is the reason he is not able to escape from the horrific thoughts about the lie and its aftermath. Tom has to manage the light to save other people, not to save himself - this is the thing he ultimately acknowledges: "He turned his attention to the rotation of the beam, and gave a bitter laugh at the thought that the dip of the light meant that the island itself was always left in darkness. A lighthouse is for others; powerless to illuminate the space closest to it" (Stedman, 2013, p. 253).

As was indicated above, Tom and Isabel are two different oceans, two different souls connected by the light produced by Lucy. She is the light that connects them but that also separates them, because the light cannot reach the depths of their inner selves. One of the souls is tortured while the other is cheerful. But still, the demons of the lie that these souls conceal hinder them in achieving ultimate peace:

"The oceans never stop. They know no beginning or end. The wind never finishes. Sometimes it disappears, but only to gather momentum from somewhere else, returning to fling itself at the island" (Stedman, 2013, p. 225).

Regarding the metaphorical meaning of the elements of nature, the oceans represent Tom and Isabel and the wind represents the lie; it gradually gains power. Though the process seems imperceptible, like land filling with water, in the end its consequences are devastating, like a huge landslide that kills people no matter if they are innocent or not.

The same tragedy happens to Tom and Isabel once they travel to the mainland on shore leave when Lucy is already two years old. There they learn of a woman who lost her infant daughter and her beloved husband in tragic circumstances two years ago. She has not given up hope and still comes to the shore in the powerful belief that their boat will appear in the distance and her family will be reunited. People consider her insane, but Hannah feels that her daughter is still alive because she simply feels it in her maternal heart, and a maternal heart is rarely wrong: "Poor Hannah never recovered. (...) Funny, how lives turn out, isn't it? 
Born to more money than you can shake a stick at; went all the way to Sydney University to get a degree in something or other; married the love of her life - and you see her now sometimes, wandering about, like she's got no home to go to" (Stedman, 2013, p. 180-181).

Knowing that Lucy's real mother is still alive and that she is still searching for her child drives Tom crazy and his sense of right and wrong - the one that he has been deliberately hiding for months - comes back as a flood. He wants to return the child immediately, but Isabel refuses to even consider the idea, because Lucy is her daughter; a gift given to her from God. Isabel was chosen to take care of the child. If God did not want her to be Lucy's mother, why would he save the boat sailing on the roaring ocean and wash it on their island? Despite acknowledging her arguments, Tom presumes that they have made a terrible mistake and that it is high time they did the right thing:

Izz. You saw what she's become. That's our doing. (...) I saw things... I saw things in the war, Izz. Things I've never told you and never will. Christ, I did things... (...) I swore I'd never make anyone suffer after that, not if I could help it. Why do you think I went on the Lights anyway? I reckoned I could maybe do a bit of good, maybe save some poor bastard from being wrecked. And now look what I've gotten into. I wouldn't want a dog to have to go through what Hannah Roennfeldt's been through! (Stedman, 2013, p. 267).

However, Tom's pangs of conscience do not solve the situation, at least for now. Isabel wants to keep the girl until she is old enough to understand the situation when they tell her the truth themselves. Tom has to step back once again, though Hannah's face haunts him everywhere. He cannot be happy when he is going against his sense of right and wrong. His marriage is fractured, because he is not able to look at Isabel in the same way as before. He feels shame when he has to look into her eyes, because he worries that Isabel would reveal the secret he has been hiding since their first shore leave - he wrote Hannah an anonymous letter to inform her that her daughter is alive and happy. Though he hopes that somehow the situation will resolve itself and Lucy will return to her real mother, a part of his mind still believes that Lucy will stay with them forever. He goes through another stage of the moral dilemma, and this time it is the hardest one. He has become a father and he loves Lucy, though he knows that she does not belong to him by law. He sees a reborn happiness in Isabel, but he knows that the feeling is temporary and one day the truth must be told.

When Lucy is four years old, the family visits the mainland for the second - and the last - time. The secret is revealed and its consequences are truly devastating for each person 
involved in the lie. Lucy is pulled out of Isabel's arms, leaving her profoundly depressed and anxious; Tom is imprisoned for alleged kidnapping and keeping of a child; Isabel's parents lose the grandchild that had helped them push back the sadness over the death of their two sons, Isabel's brothers. Lucy is taken out of the only home she has ever known and put into a family of a woman she refuses to obey and call mother, and Hannah is desperate because the child she has finally found is so different from the one she had lost.

In the end, one thing should naturally happen: Tom's victory over his darker self. Even though he has ended up in prison, he should be satisfied that justice was done and Lucy is with a woman she has always belonged to. However, what follows is another chapter of his never-ending struggle with morality. Tom's newly acquired situation throws a totally different light on Isabel and Hannah. He is able to see what both women have gone through when their children were taken away from them and how much they must have suffered. He made one woman happy at the expense of the other:

He cannot reconcile the grief he feels at what he has done and the profound relief that runs through him. Two opposing physical forces, they create an inexplicable reaction overpowered by a third, stronger force - the knowledge of having deprived his wife of a child. As fresh and raw as being spiked on a meat hook, he feels loss: what Hannah Roennfeldt must have felt; what Isabel has felt so many times, and grips her again now. He begins to wonder how he could have inflicted such suffering. He begins to wonder what the bloody hell he's done (Stedman, 2013, p. 305-306).

Eventually, it appears that there is only one thing he could do to make the confusion disappear, or at least make it less intense: to bear the guilt on his shoulders instead of Isabel, since she has already suffered enough and he was the cause of her pain.

The Light Between Oceans offers a complex and morally astounding story of two people who are naturally good but who make bad choices. The scenarios that the author creates do not allow the readers to stop thinking about what they would do if they were in the shoes of Tom or Isabel. Despite knowing that what they did was morally wrong, it is impossible to judge them. Stedman makes her readers feel utterly sympathetic towards her characters, because they are portrayed so believably and thus any culture or any nation can relate to the issues their story raises. Its theme is universal; it can be applied to any era or country. Moreover, the author shows her immense talent in observing and understanding the feelings and internal battles of human beings. She is able to dive deep into the dark world of Tom Sherbourne and depict his post-war state of mind in a truly authentic way. Thus she proves that the problems tormenting the Lost Generation were global and affected people even in the farthest corners of the world. 
Right and wrong, loss and gain, love and hatred, mistakes and forgiveness - these are the opposites that Stedman explores in detail in her debut. On the one hand, she creates a world in which one person's happiness is another's despair, but on the other hand, she emphasizes that love and forgiveness are powerful sources providing light strong enough to defeat even the darkest consequences of misjudged situations. After all, human beings are fragile and so is our morality.

One of the most significant messages that the novel conveys is that forgiveness is one of the primary virtues. At the end of the story, Stedman provides a new image of the couple, now old enough to recall peacefully the horrific passages of their relationship. While their lives are gradually coming to an end, Tom and Isabel show that they have managed to start anew and have a good and fruitful marriage, despite the tragedies it was once accompanied by. Their love has been deepened because they were able to forgive each other for the pain they caused and the mistakes they made. Stedman proves that forgiveness has an incredible healing power, and even more if you are able to forgive not only people around you but also yourself.

\section{Works Cited:}

"Ted Smout", 2010. Australians at War Film Archive, Australian Government - Department of Veterans' Affairs. [cit. 2014-08-12]. Available at:

http://www.australiansatwarfilmarchive.gov.au/aawfa/pdf/smout3.pdf

Kijas, J. Life Under the Light. Lighthouse Families of New South Wales. Sydney: Office of Environment \& Heritage, State of NSW. Available at:

http://www.environment.nsw.gov.au/resources/cultureheritage/20110283LighthouseHistory.p df

Livengood, S. Psychological Trauma: Shell Shock during WWI. Fall 2011. Journal of History and Social Science. [cit. 2014-08-12]. Available at:

https://hssjournal.files.wordpress.com/2012/01/shelby-shell-shock.pdf

Stedman, M. L. 2013. The Light Between Oceans. London: Transworld Publishers, Black

Swan edition.

Natália Čechová

Department of English and American Studies

Faculty of Arts

Constantine the Philosopher University in Nitra

Štefánikova 67

94974 Nitra, Slovakia

natalia.cechova@ukf.sk 